\title{
Pasture Forages, Supplementation Rate, and Stocking Rate Effects on Dairy Cow Performance ${ }^{1}$
}

\author{
J. H. Fike*, C. R. Staples†, L. E. Sollenbergerł, B. Macoon§, and J. E. Moore\| \\ *Department of Crop and Soil Environmental Sciences \\ Virginia Polytechnic Institute and State University, Blacksburg, VA 24061 \\ †Department of Animal Sciences and \\ ‡Department of Agronomy, University of Florida, Gainesville, FL 32611 \\ $\S$ Department of Plant and Soil Sciences, Mississippi State University \\ Central Mississippi Research and Extension Center, Raymond, MS 39154 \\ ॥Professor Emeritus. Stillwater, OK 74074
}

\begin{abstract}
Objectives were to evaluate effects of forage species, stocking rate, and supplementation rate on performance and physiology of grazing lactating Holstein cows under intensive rotational stocking management during summer. Eight treatments were arranged in a $2 \times 2 \times 2$ factorial design. Animals $(\mathrm{n}=62)$ grazed pastures of Tifton 85 bermudagrass or Florigraze rhizoma peanut, a tropical legume. Low and high stocking rates were 7.5 and 10.0 cows/ha for bermudagrass and 5.0 and $7.5 \mathrm{cows} / \mathrm{ha}$ for rhizoma peanut. Within each forage-stocking rate combination, cows were fed supplement at 0.33 or $0.5 \mathrm{~kg}$ of supplement (as-fed basis) $/ \mathrm{kg}$ daily milk production. Cows grazing rhizoma peanut pastures produced more milk (16.9 vs. $15.4 \mathrm{~kg} / \mathrm{d}$ ) but had higher rectal temperatures $\left(39.4\right.$ vs. $\left.39.1^{\circ} \mathrm{C}\right)$. Milk production per cow was improved at the higher stocking rate for bermudagrass but was reduced at the higher stocking rate for peanuts. Increasing supplementation rate boosted plasma glucose, milk production, and milk protein percent. Increased supplementation rate had a greater positive impact on milk production of cows grazing bermudagrass compared to rhizoma peanut ( 21.9 vs. $10.6 \%$ increase) due to a lower substitution of grain for forage intake. Organic matter intakes of forage, supplement, and total diet were greatest by cows grazing rhizoma peanut pastures and averaged 12.4, 6.1 , and $18.5 \mathrm{~kg} / \mathrm{d}$ compared to $9.2,5.4$, and $14.6 \mathrm{~kg} / \mathrm{d}$ for cows grazing bermudagrass. Despite lower individual feed intake and performance, production per unit land area was $29 \%$ greater (112 vs. $90 \mathrm{~kg}$ of milk/ha per
\end{abstract}

\footnotetext{
Received June 20, 2002.

Accepted September 12, 2002

Corresponding author: Dr. C. R. Staples; e-mail: staples@animal. ufl.edu.

${ }^{1}$ This research was supported by the Florida Agricultural Experiment Station and approved for publication as Journal Series No. R-08909. The work was partially funded by grant \#99-34135-1857 from USDA.
}

d) for cows grazing bermudagrass due to the greater stocking rate possible with that forage. Only cows supplemented at the high rate and kept at the high stocking rate on bermudagrass maintained body weight. Cows on other treatments lost body weight. Tifton 85 bermudagrass appears to be an excellent summer forage for dairy cows grazing in the southeastern U.S. given its nutritive value characteristics and high yields. Optimum stocking rate may be as high as 10 cows/ha during times of peak growth of forage for low-to-moderately producing cows fed supplement. Furthermore, the positive milk production response to additional supplement when cows grazed Tifton 85 pastures $(0.8 \mathrm{~kg} / \mathrm{kg}$ of supplement), indicates the value of providing supplement to cows grazing this moderate quality forage.

(Key words: bermudagrass, grazing, pasture)

Abbreviation key: HA = herbage allowance, $\mathbf{H M}=$ herbage mass, IVOMD = in vitro organic matter digestibility, $\mathbf{M U N}$ = milk urea nitrogen, $\mathbf{O M I}=$ organic matter intake, OMIBW = OMI as a percent of BW, PUN = plasma urea nitrogen, $\mathbf{R P}=$ Florigraze rhizoma peanut, $\mathbf{S R}=$ stocking rate, $\mathbf{S U P}=$ supplementation rate.

\section{INTRODUCTION}

The economics of dairying in the United States has encouraged farmers to search for new ways to reduce costs. While increasing herd size is a common option, many smaller producers have begun using intensive rotational stocking systems to reduce inputs (Parker et al., 1992; Dartt et al., 1999). However, for producers using grazing in the Southeast, the climate presents unique challenges to production. The ability to grow superior quality forages is of particular concern for graziers (producers using grazing systems). Perennial, warm-season forages typically are of lower nutritive value than either cool-season perennials or warm-season annuals, but they do have the agronomic advantage of being adapted to the region. Thus, despite their lower quality, forages such as bahiagrass (Paspalum nota- 
tum) and bermudagrass (Cynodon dactylon (L.) Pers.) are the foundation of forage production systems for grazing animals in the Southeast.

Recent literature regarding grazing dairy systems in the southeastern United States is limited. The majority of data pertaining to dairy cow grazing in North America has been published by researchers in the Northeast and Midwest under very different environmental conditions (Hongerholt and Muller, 1998; Reis and Combs, 2000). Some research from Australia (King and Stockdale, 1980) and other tropical areas may be applicable to the southeastern environment, but the forages grown are typically of different genera and the amounts of concentrate fed are less than the amounts provided by U.S. producers. Thus, our first objective was to investigate animal productivity when two recently released forages were used as a grazing base for lactating dairy cows.

Supplemental concentrate feeds are typically fed to lactating dairy cattle in the U.S. The availability of inexpensive concentrates makes this possible and desirable, especially since wholly forage-based diets cannot meet the energy requirements of higher-producing, lactating dairy cows. However, supplement can have a large effect on DMI and rumen function, and thus production responses to supplement are inconsistent (Berzaghi et al., 1996; Jones-Endsley et al., 1997; Hongerholt and Muller, 1998; Reis and Combs, 2000). Providing supplement is usually profitable in the U.S., but factors such as pasture quantity and quality and animal management should be included when considering the efficacy of supplementation. Thus, our second objective was to test animal and pasture production responses to two rates of supplementation within each forage base.

The response to forage and supplement may depend upon stocking rate. Most models describing the effect of stocking rate on production indicate that while production per animal decreases with increasing stocking rate, production per land area increases. Optimum pasture utilization typically requires stocking rates at which forage consumption is limited, but excessively high stocking rates may limit production per land area if pasture productivity is compromised. With high stocking rates, however, the response to forage type or supplement may be greater than in situations in which forage is not limiting. Because information about the effect of stocking rate and its interactions with forage type and supplement rate on the productivity of grazing, lactating dairy cattle was limited, our third objective was to determine animal and pasture production responses to two stocking rates within each forage-supplementation rate combination.

\section{MATERIALS AND METHODS}

\section{Cows, Design, and Treatments}

On 9 July, primiparous $(\mathrm{n}=31)$ and multiparous ( $\mathrm{n}$ $=31$, mean parity $=3.1$ ) Holstein cows (mean DIM = $126 \pm 38$ ) were assigned to one of eight management treatments arranged in a $2 \times 2 \times 2$ factorial design. The number of primiparous and multiparous cows were assigned equally across treatments. The main treatment factors were 1) forage species grazed: bermudagrass (Cynodon dactylon $\times C$. nlemfuensis cv. Tifton 85; BG) or rhizoma peanut (Arachis glabrata cv. Florigraze; RP), 2) supplementation rate (SUP): 0.33 or 0.5 $\mathrm{kg}$ of supplement (as-is)/kg of daily milk production, and 3) stocking rate (SR): 7.5 or 10.0 cows/ha for cows grazing BG pastures and 5 or 7.5 cows/ha for cows grazing RP pastures. These SR were selected based upon research conducted the previous year. Size of paddocks and number of cows assigned to paddocks were adjusted to insure the correct SR. Pastures were replicated twice.

Each of the three experimental periods was $28 \mathrm{~d}$ in duration, with the first $14 \mathrm{~d}$ of each period used for adjustment to a newly assigned treatment and the last $14 \mathrm{~d}$ for collection of data. Cows were randomly allotted to a new treatment each successive period with the restriction that no cow received the same treatment more than once during the experiment, and that primiparous and multiparous cows were equally represented across the treatments.

Soils were primarily of the Tavares (hyperthermic, uncoated Typic Quartzipsamments) and Chipley (thermic, coated Aquic Quartzipsamments) series with average $\mathrm{P}, \mathrm{K}$, and $\mathrm{Mg}$ concentrations of 99,26 , and $50 \mathrm{mg} /$ $\mathrm{kg}$, respectively.

Bermudagrass pastures were fertilized with $45 \mathrm{~kg}$ of N/ha as $\mathrm{NH}_{4} \mathrm{NO}_{3}$ on 21 May, 8 June, and 7 August. A fourth application of $56 \mathrm{~kg}$ of N/ha occurred on 11 September. Potassium was applied at $40 \mathrm{~kg}$ of $\mathrm{K}_{2} \mathrm{O} / \mathrm{ha}$ on 7 June. Pastures were irrigated from 15 May to 12 June at a rate of $25 \mathrm{~mm} / \mathrm{wk}$ for a total of $100 \mathrm{~mm}$ of water. Due to the loss of BG stand, one replicate pasture assigned the low SR low SUP treatment was removed from the study.

In order to stage the forage growth, Holstein heifers (approximately $400 \mathrm{~kg} \mathrm{BW)} \mathrm{grazed} \mathrm{both} \mathrm{forages} \mathrm{from}$ 10 June to 6 July. Stocking rates were 10 and 5 heifers/ ha for BG and RP pastures, respectively, and animals were fed no supplement. The trial was from 9 July through 2 October 1996.

Bermudagrass and RP pastures were divided into 22 and 29 paddocks respectively, allowing for 21- and 28$\mathrm{d}$ rest periods between grazing events. Cows were kept in the bounds of individual paddocks with polywire fenc- 
Table 1. Ingredient and chemical composition of supplement fed to lactating Holstein cows on pasture.

\begin{tabular}{lc}
\hline Item & \\
\hline Ingredients (\% of DM) & \\
Hominy & 35.3 \\
Soybean hulls & 23.9 \\
Soybean meal $(48 \%)$ & 9.6 \\
Whole cottonseed & 19.8 \\
Dried cane molasses & 5.0 \\
Mineral mix 1 & 2.5 \\
Calcium carbonate & 1.3 \\
Trace mineralized salt ${ }^{2}$ & 1.3 \\
Sodium bicarbonate & 1.3 \\
Chemical composition & \\
Dry matter, $\%$ & 91.4 \\
NEL, Mcal/kg of DM ${ }^{3}$ & 1.89 \\
NDF, \% of DM & 42.5 \\
ADF, \% of DM & 27.7 \\
CP, \% of DM & 18.0 \\
Ca, \% of DM & 0.91 \\
P, \% of DM & 0.61 \\
Mg, \% of DM & 0.34 \\
K, \% of DM & 1.33 \\
Na, \% of DM & 0.93 \\
S, \% of DM & 0.20 \\
Cl, \% of DM & 0.82 \\
Fe, ppm, of DM & 355 \\
Zn, ppm, of DM & 159 \\
Cu, ppm, of DM & 33 \\
Mn, ppm, of DM & 66 \\
\hline
\end{tabular}

${ }^{1}$ Composition: $3.8 \% \mathrm{~N}, 10.5 \% \mathrm{Ca}, 3 \% \mathrm{P}, 4.5 \% \mathrm{~K}, 2 \% \mathrm{Mg}, 7.4 \% \mathrm{Na}$, $1.1 \% \mathrm{~S}, 5.4 \% \mathrm{Cl}, 1525 \mathrm{ppm} \mathrm{Mn}, 1750 \mathrm{ppm} \mathrm{Fe}, 425 \mathrm{ppm} \mathrm{Cu}, 1500 \mathrm{ppm}$ $\mathrm{Zn}, 12.8 \mathrm{ppm} \mathrm{I}, 49 \mathrm{ppm} \mathrm{Co}, 24.2 \mathrm{IU}$ of vitamin $\mathrm{A} / \mathrm{g}, 35.2 \mathrm{IU}$ of vitamin $\mathrm{D} / \mathrm{g}$, and $0.88 \mathrm{IU}$ of vitamin $\mathrm{E} / \mathrm{g}$.

${ }^{2}$ Composition (g/100 g): NaCl, 92 to $97 ; \mathrm{Mn},>0.25 ; \mathrm{Fe},>0.2 ; \mathrm{Cu}$, $>0.033 ; \mathrm{I},>0.007$; Zn, > 0.005; Co, > 0.0025.

${ }^{3}$ Calculated using 1989 NRC values for whole cottonseed.

ing and paddocks were back-fenced. Cows were provided shade structures and water tubs that were moved with the cows to a fresh paddock each morning. Shade structures were 3-m tall, constructed of galvanized metal pipe, stretched with $80 \%$ shade cloth, and designed to provide a minimum of $4.65 \mathrm{~m}^{2}$ of shade/cow.

Cows walked 0.4 to $1.2 \mathrm{~km}$ from pasture to the parlor for milking and back to pastures twice daily. Cows were milked at approximately 0600 and $1800 \mathrm{~h}$. A supplement (Table 1) was fed after each milking in troughs located in each paddock. The amount of supplement fed was recalculated twice weekly. Feed troughs were moved with the shade and water tubs each day.

\section{Experimental Procedures}

Animal measures. Milk weights were recorded at each milking. Milk samples were collected at six consecutive milkings during each of the last 2 wk of each period. Samples were analyzed by Southeast Dairy Labs (McDonough, GA) for fat, protein, milk urea nitrogen (MUN) concentrations and SCC.
Cows were weighed on three consecutive days at the initiation of the trial and at the end of each period. Body weights were recorded after the a.m. milking and prior to feeding of supplement. Body condition scores were recorded on one of the weigh days within each period.

Respiration rates were recorded on $1 \mathrm{~d}$ of each period. Movement of the flank or bobbing of the head was monitored over 1-min intervals. Measures took place while cows were on pasture during the time of greatest potential ambient temperature (approximately 1400 to 1600 h). Rectal temperatures were measured with small, digital thermometers (Medline, Medline Industries, Inc., Mundelein, IL) after the p.m. milking.

Blood was obtained from the coccygeal vessels on $d$ 22 or 23 of each period. Samples were collected into $9 \mathrm{ml}$ Na-heparinized syringes (Luer Monovette, LH, Sarstedt, Inc., Newton, NC) after the p.m. milking and placed on ice. Blood was centrifuged $(2000 \times g$ for 30 min) and plasma was collected and frozen at $-20^{\circ} \mathrm{C}$ on the same day. Plasma from Experiment 1 was analyzed for urea N (PUN) (Kit 535-A, Sigma, St. Louis, MO) and glucose (autoanalyzer II, Bran+Luebbe, Buffalo Grove, IL).

Chromium-mordanted fiber was used as an inert marker to determine organic matter intake (OMI). Each period, forage was collected across all pastures and composited for each species. Efforts were made to gather forage of quality similar to that consumed. Forages were dried at $55^{\circ} \mathrm{C}$ and ground with a stainless steel Thomas-Wiley Laboratory Mill (Thomas Scientific, Philadelphia, PA) using a 2-mm screen. Fiber from the forage was chromium mordanted according to the method of Udén et al. (1980). $3 \pm 0.02 \mathrm{~g}$ (air dry) of mordanted fiber were weighed into 28 -g gelatin capsules (Jorgenson Laboratories, Loveland, CO). Average Cr concentrations were 46,000 and $53,000 \mathrm{ppm}$ for the $\mathrm{BG}$ and RP fibers, respectively.

In each period, 32 cows were orally dosed with nine gelatin capsules containing Cr-mordanted fiber ( $27 \mathrm{~g}$, as-fed) from their respective forage assignments. Capsules were administered with a multiple dose balling gun (NASCO, Ft. Atkinson, WI).

Cows were dosed after the evening milking on d 25, and fecal samples were collected at approximately 0 , $12,15,18,21,24,27,36,42,48,60,72$, and $84 \mathrm{~h}$ postdosing. Collections were made on pasture at $h 15$, $18,21,27$, and 42 , while at the remaining times grab samples were taken in holding pens at the milking parlor.

Fecal samples were refrigerated or frozen immediately after collection. Samples were dried at $55^{\circ} \mathrm{C}$, then ground through a 1-mm screen with a Wiley mill. Samples $\left(2 \mathrm{~g}\right.$, as-is) were dried at $105^{\circ} \mathrm{C}$ and ashed at $550^{\circ} \mathrm{C}$ 
for determination of DM and OM according to AOAC (1990) procedures. Ash was digested in a solution of $\mathrm{H}_{2} \mathrm{PO}_{4}$ (with added $\mathrm{MnSO}_{4}$ ) and $\mathrm{KBrO}_{3}$ heated with a hot plate and analyzed for $\mathrm{Cr}$ by atomic absorption spectrophotometry (Williams et al., 1962).

Chromium excretion patterns were evaluated with PROC NLIN using the method of Pond et al. (1987). Parameters generated by this program were used to estimate fecal output for each cow. Estimates were based on the following assumptions:

1. supplement intake was the same for all cows within a pasture replicate,

2. supplement digestibility was constant regardless of forage intake, and

3. digestibility of forage was affected by the level of supplement intake, as determined by the equation of Moore et al. (1999).

Theoretically, fecal output should equal total intake multiplied by the indigestible fraction of a feed. Because fecal output observed, based on the mordanted-fiber methodology, was not equal to the fecal output predicted based on forage and supplement digestibilities, an iterative SAS (1991) program (developed by Dr. J. E. Moore) was employed to adjust the estimate of forage intake until the difference between fecal output observed and predicted differed by less than $0.01 \mathrm{~kg} / \mathrm{d}$.

Expected diet digestibility $(\%)=[($ forage intake, $\mathrm{kg}$ * forage digestibility, \%) + (supplement intake, $\mathrm{kg} *$ supplement digestibility, \%)]/total intake, kg. Because feeding concentrate supplements often alters forage digestibility, the iterative program also employed the equation of Moore et al. (1999) to adjust total diet digestibility.

Pasture measures. A double sampling technique was used to quantify pre- and postgraze forage mass (Meijs et al., 1982). Every 2 wk of each period, 25 measures of forage height were taken using a $0.25-\mathrm{m}^{2}$, aluminum disk meter. Pregraze measures were recorded in paddocks to be grazed the following day, and postgraze measures were made 1 or $2 \mathrm{~d}$ after the cows had grazed the paddock. At one sampling event in each period, 2 or 3 samples were collected pre- and postgraze from one paddock per pasture to establish a relationship between herbage mass (HM) and the recorded disk heights. After dropping the plate of the disk meter on the forage, a metal ring was used to mark the outline of the disk meter, and the forage within the ring was clipped at ground level. The forage was dried at $55^{\circ} \mathrm{C}$ for a minimum of $48 \mathrm{~h}$ to a constant weight.

Equations to predict pre- and postgraze forage mass were calculated by regressing mass on disk height measured at double sampling sites. Regression equations were assessed for the following data: all samples within a forage species, all pre- or all postgraze samples within a forage, and pre- or postgraze samples within a period and within a forage. After review of the data, HM equations were derived from pre- and postgraze measurements within periods within a forage. Herbage allowance (HA) represents $\mathrm{kg}$ of herbage DM per kg of animal BW. Estimates of HA were calculated as $0.5 \times$ (pregraze + postgraze $\mathrm{HM}, \mathrm{kg} / \mathrm{ha}$ )/(average $\mathrm{BW}, \mathrm{kg} / \mathrm{cow} \times$ cows/ ha).

Feed sampling. Once per period, forage was collected for characterization of chemical composition and digestibility. Attempts were made to collect forage similar to that consumed after first inspecting an adjacent, grazed paddock. 20 to 30 grab samples were taken from the next paddock to be grazed in each pasture, composited within paddock, dried at least $48 \mathrm{~h}$ at $55^{\circ} \mathrm{C}$ and ground through a $1-\mathrm{mm}$ screen with a stainless steel Thomas-Wiley Laboratory mill. Samples were analyzed for in vitro OM digestibility (Moore and Mott, 1974), $\mathrm{OM}\left(105^{\circ} \mathrm{C}\right.$ for $8 \mathrm{~h}$ ), $\mathrm{NDF}$ (Goering and Van Soest, 1970), and N (Gallaher et al., 1975; Hambleton, 1977). Forage samples also were composited across periods and treatments and analyzed for minerals by DHIA forage testing lab, Ithaca, NY. Supplements were sampled weekly, composited, and analyzed for $\mathrm{CP}, \mathrm{NDF}, \mathrm{ADF}$, and minerals by DHIA forage testing lab, Ithaca, NY.

\section{Statistical Analysis}

Data were analyzed using the GLM procedure of SAS (1991) with the following model:

$$
\begin{gathered}
\mathrm{Y}_{\mathrm{ijklmno}}=\mu+\rho_{\mathrm{j}}+\kappa(\rho)_{\mathrm{k}(\mathrm{j})}+\alpha_{\mathrm{l}}+\beta_{\mathrm{m}}+(\alpha \beta)_{\mathrm{lm}}+\gamma_{\mathrm{n}} \\
+(\alpha \gamma)_{\mathrm{ln}}+(\beta \gamma)_{\mathrm{mn}}+(\alpha \beta \gamma)_{\operatorname{lmn}}+(\rho \alpha)_{\mathrm{jl}}+(\rho \beta)_{\mathrm{lm}}+(\rho \alpha \beta)_{\mathrm{jlm}} \\
+\rho \gamma_{\mathrm{jn}}+(\rho \alpha \gamma)_{\mathrm{jln}}+(\rho \beta \gamma)_{\mathrm{jmn}}+(\rho \alpha \beta \gamma)_{\mathrm{jlmn}}+\nu_{\mathrm{o}}+(\rho \nu)_{\mathrm{jo}} \\
+\delta_{\mathrm{p}}(\alpha \beta \gamma)_{\mathrm{lmn}}+\varepsilon_{\mathrm{jklmnop}}
\end{gathered}
$$

where

$$
\begin{aligned}
\mu & =\text { overall mean } \\
\rho_{\mathrm{j}} & =\text { effect of parity, } \\
\kappa(\rho)_{\mathrm{k}(\mathrm{j})}= & \text { effect of cow within parity, } \\
\alpha_{\mathrm{l}}= & \text { effect of forage, } \\
\beta_{\mathrm{m}}= & \text { effect of SUP } \\
\gamma_{\mathrm{n}}= & \text { effect of SR, } \\
\nu_{\mathrm{o}}= & \text { effect of period, } \\
\delta_{\mathrm{p}}= & \text { effect of pasture replicate within forage, } \\
& \text { SUP and SR treatments, and } \\
\varepsilon_{\mathrm{jklmnop}}= & \text { effect of residual error. }
\end{aligned}
$$

Single degree of freedom orthogonal contrasts were made to test for treatment effects. Treatments were considered different at $P$ levels $<0.05$ and trends are reported for $P<0.10$. Classes were cow, parity, forage, SR, SUP, pasture, and period. Cow within parity was 
Table 2. Effect of stocking rate (SR) and supplementation rate (SUP) on CP, in vitro organic matter digestibility (IVOMD), and NDF concentrations in Tifton 85 bermudagrass and Florigraze rhizoma peanut pastures. Samples were hand-plucked once each period based upon visual appraisal of forage consumed by grazing cows.

\begin{tabular}{|c|c|c|c|c|c|c|c|c|c|c|c|c|c|c|c|c|}
\hline & Tift & $\begin{array}{l}\text { n } 85 \text { b } \\
\text { Stocki }\end{array}$ & $\begin{array}{l}\text { rmuda } \\
\text { g rate }\end{array}$ & rass & Florig & $\begin{array}{l}\text { aze rhi } \\
\text { Stockir }\end{array}$ & $\begin{array}{l}\text { toma } p \\
\text { g rate }\end{array}$ & anut & \multirow{2}{*}{ SEM } & \multirow{2}{*}{ Forage } & \multirow{2}{*}{ SR } & \multirow{2}{*}{ SUP } & \multicolumn{3}{|c|}{ Probability } & \multirow{2}{*}{$\begin{array}{l}\text { Forage } \\
\times \text { SR } \\
\times \text { SUP }\end{array}$} \\
\hline & \multicolumn{2}{|c|}{ High } & \multicolumn{2}{|c|}{ Low } & \multicolumn{2}{|c|}{ High } & \multicolumn{2}{|c|}{ Low } & & & & & & & & \\
\hline & \multicolumn{8}{|c|}{ - Supplementation rate $(\mathrm{kg}$, as-fed/kg of milk per $\mathrm{d})$ - } & & & & & & & & \\
\hline $\mathrm{CP}, \%$ & 14.3 & 12.8 & 13.0 & 13.2 & 16.6 & 16.7 & 16.9 & 16.2 & 0.6 & $* * *$ & $\mathrm{NS}^{3}$ & NS & NS & NS & NS & NS \\
\hline IVOMD, \% & 63.7 & 62.2 & 62.8 & 62.3 & 71.2 & 71.1 & 71.3 & 71.5 & 1.1 & $* * *$ & NS & NS & NS & NS & NS & NS \\
\hline
\end{tabular}

${ }^{1}$ High and low stocking rates were 10.0 and 7.5 cows/ha on Tifton 85 bermudagrass pastures.

${ }^{2}$ High and low stocking rates were 7.5 and 5.0 cows/ha on Florigraze rhizome peanut pastures.

${ }^{3} \mathrm{NS}=$ not significant $(P>0.10)$.

$* * * P<0.001$.

the error term for parity effects and pasture within $($ forage $\times \mathrm{SR} \times \mathrm{SUP})$ was the error term for the main treatment effects and their interactions.

\section{RESULTS AND DISCUSSION}

\section{Forage Composition}

Estimates of in vitro digestibility and nutritive value of RP were greater than for BG (Table 2). The RP pastures averaged 3.3 percentage units more $\mathrm{CP}$ (16.6 vs. $13.3 \%$ ), contained less NDF (45.5 vs. $80.4 \%$ ), and had greater average IVOMD (71.3 vs. $62.7 \%)$. These estimates of nutritive value are similar to values reported by others (Gelaye et al., 1990; Mandebvu et al., 1998). Neither stocking rate nor supplementation rate influenced the $\mathrm{CP}, \mathrm{NDF}$, or IVOMD values of the forages.

\section{Herbage Mass and Herbage Allowance}

Forage effects. Pregraze HM of BG pastures averaged $2850 \mathrm{~kg} /$ ha more DM $(P<0.001)$ than RP pastures (6760 vs. $3920 \mathrm{~kg} / \mathrm{ha}$, Table 3). This advantage for BG pastures carried over to postgraze HM measures as well (5460 vs. $2440 \mathrm{~kg} / \mathrm{ha}$ for BG and RP pastures, respectively). As with HM, HA was greater $(P<0.001)$ for BG than for RP pastures (1.4 vs. $1.0 \mathrm{~kg}$ of forage/ $\mathrm{kg}$ of BW).

Stocking rate effects. Lower SR resulted in greater $(P<0.05)$ pregraze HM (5490 vs. $5190 \mathrm{~kg} / \mathrm{ha})$ across forage species (Table 3 ). This was likely due to carryover effects from previous grazing events within each grazing season as reflected in differences in postgraze HM. The difference between SR treatments for postgraze HM (4210 vs. $3690 \mathrm{~kg}$ of DM/ha for low and high SR, respectively) was approximately $75 \%$ larger than the difference between SR treatments for pregraze HM. However the effects of SR on postgraze HM were influ- enced by the type of pasture grazed. The higher SR used on RP-pastures reduced postgraze HM from 2890 to $1980 \mathrm{~kg} / \mathrm{ha}$ whereas SR had little effect on postgraze HM of BG pastures (5540 vs. $5390 \mathrm{~kg} / \mathrm{ha}$, forage by SR interaction, $P<0.05$ ). Intake may be limited when HM in tropical grass-legume pastures is $<2000 \mathrm{~kg} / \mathrm{ha}$ (Cowan and O'Grady, 1976). Pregraze HM exceeded $2000 \mathrm{~kg} / \mathrm{ha}$ in all treatments. However, the postgraze $\mathrm{HM}$ of RP pastures managed with the high SR and low SUP rate treatments was $1770 \mathrm{~kg} / \mathrm{ha}$, suggesting that forage may have been limiting. Therefore the higher SR of 7.5 cows/ha used on RP pastures may be getting beyond the carrying capacity of RP for low-producing lactating dairy cows. This is supported by the HA data. Herbage allowance dropped from 1.3 to about $0.75 \mathrm{~kg}$ of RP/kg of BW for the high SR treatment. A HA below 1.0 has been associated with reduced animal performance and is thought to be an indicator of a lack of sufficient forage for ad libitum consumption (Sollenberger and Moore, 1997). Greater SR resulted in decreased $(P<0.001)$ HA by $49 \%(0.97$ vs. $1.45 \mathrm{~kg}$ of forage/kg of BW).

\section{Milk Production and Composition}

Forage effects. Cows grazing RP pastures produced approximately $10 \%$ more $(P<0.001)$ milk than cows grazing BG (16.9 vs. $15.4 \mathrm{~kg} / \mathrm{cow}$ per d; Table 4$)$. This advantage in milk production coupled with similar milk fat concentrations (3.59 vs. $3.55 \%)$ resulted in greater production of FCM $(P<0.01)$ and milk fat $(P<0.05)$ by cows grazing RP. Milk protein concentrations were unaffected by forage species but milk protein production was greater $(P<0.01)$ due to the effect of RP on milk yield. The tendency $(P<0.10)$ for elevated MUN concentrations when cows grazed RP (17.7 vs. $17.1 \mathrm{mg} /$ $100 \mathrm{ml}$ of milk suggests a lower utilization of dietary 
$\mathrm{N}$ or simply greater $\mathrm{N}$ intakes by cows grazing $\mathrm{RP}$. These values exceed that recommended $(\sim 11.5 \mathrm{mg} \%)$ by Roseler et al. (1993) who fed diets balanced for RDP and nonfiber carbohydrates but are similar (Hongerholt and Muller, 1998) or less than MUN values reported previously (Reis and Combs, 2000) for grazing dairy cows fed supplement.

Stocking rate effects. The main effect of SR affected only MUN, with the concentration of MUN being lower $(P<0.05)$ in cows managed at the lower SR $(17.0$ vs. $17.8 \mathrm{mg} \%$; Table 4). Stocking rate did influence animal performance differently depending upon the forage species grazed. Stocking BG pastures at greater rates (10 vs. 7.5 cows/ha) resulted in increased production of milk, FCM, and milk protein whereas greater SR on RP pastures ( 7.5 vs. 5.0 cows/ha) decreased these production measures (forage by $\mathrm{SR}$ interaction, $P<0.05$; Table 4; Figure 1). Nutritive value of BG or RP were not changed when SR was changed (Table 2); however, $\mathrm{HA}$ of RP decreased with increasing stocking rate (Table 3) suggesting that high quality forage may have been lacking leading to a small reduction in production of milk and milk components.

Supplementation rate effects. Feeding cows at the greater SUP rate resulted in $15 \%$ (17.3 vs. $15.0 \mathrm{~kg} / \mathrm{cow}$ per d) greater $(P<0.001)$ milk production (Table 4$)$. A similar increase $(P<0.001)$ was observed for FCM.

The percent increase in milk production from greater SUP fed to cows grazing BG was more than double (21.9 vs. $10.6 \%$ ) that increase of cows grazing RP pastures (forage species $\times \mathrm{SUP}$ interaction, $P<0.05$; Figure 2), with a similar tendency $(P<0.10)$ observed for FCM. The greater production response with additional supplement for cows grazing BG is indicative of a lower substitution rate of supplement for the lower quality forage (Arriaga-Jordan and Holmes, 1986; Blaxter and Wilson, 1963; Golding et al., 1976). Each additional kg of supplement fed above the low SUP amount resulted in an additional $0.79 \mathrm{~kg}$ of milk/cow per $\mathrm{d}$ for cows grazing BG vs. an additional $0.46 \mathrm{~kg}$ of milk/cow per d for cows grazing RP.

Milk fat percentage was unchanged by additional supplement (3.53 vs. $3.60 \%$ for high vs. low SUP, respectively) but milk fat production increased $(P<0.01)$ with greater SUP as a result of greater milk production. Milk protein percentage was increased $(P<0.01)$ with provision of additional supplement (3.05 vs. 2.97\%), however the increase was greater when cows grazed RP (3.06 vs. $2.94 \%)$ compared to BG (3.03 vs. $3.00 \%)$ pastures (forage species by SUP interaction, $P<0.05$; Figure 3$)$. The $\mathrm{CP}$ in RP may not be as digestible as other forage proteins (Staples et al., 1997), thus the protein provided by additional supplement could have 
Table 4. Effect of stocking rate (SR) and supplementation rate (SUP) on milk production/ha and on production and composition of milk from Holsteins grazing Tifton 85 bermudagrass and Florigraze rhizoma peanut pastures during the summer.

\begin{tabular}{|c|c|c|c|c|c|c|c|c|c|c|c|c|c|c|c|c|}
\hline \multirow[b]{3}{*}{ Item } & \multicolumn{4}{|c|}{$\begin{array}{l}\text { Tifton } 85 \text { bermudagrass } \\
\text { Stocking rate }^{1}\end{array}$} & \multicolumn{4}{|c|}{$\begin{array}{l}\text { Florigraze rhizoma peanut } \\
\text { Stocking } \text { rate }^{2}\end{array}$} & \multirow[b]{3}{*}{ SEM } & \multirow[b]{3}{*}{ Forage } & \multirow[b]{3}{*}{ SR } & \multicolumn{4}{|c|}{ Probability } & \multirow{3}{*}{$\begin{array}{l}\text { Forage } \\
\times \text { SR } \\
\times \text { SUP }\end{array}$} \\
\hline & \multicolumn{2}{|c|}{ High } & \multicolumn{2}{|c|}{ Low } & \multicolumn{2}{|c|}{ High } & \multicolumn{2}{|c|}{ Low } & & & & & & & & \\
\hline & $0.5: 1$ & $0.33: 1$ & $0.5: 1$ & $0.33: 1$ & $0.5: 1$ & $0.33: 1$ & $0.5: 1$ & $0.33: 1$ & & & & SUP & $\times \mathrm{SR}$ & $\times$ SUP & $\times$ SUP & \\
\hline & & - Supp & mentati & rate ( & as-fed/k & of milk $\mathrm{p}$ & (d) & & & & & & & & & \\
\hline Milk, kg/ha per d & 143 & 119 & 103 & 82 & 115 & 100 & 71 & 62 & 5 & $* * *$ & $* * *$ & $* *$ & NS & $\mathrm{NS}$ & NS & NS \\
\hline Milk, kg/d & 17.3 & 14.3 & 16.6 & 13.5 & 17.3 & 15.8 & 18.2 & 16.3 & 0.4 & $* * *$ & NS & $* * *$ & $*$ & $*$ & NS & NS \\
\hline $\mathrm{FCM}, \mathrm{kg} / \mathrm{d}$ & 15.9 & 13.4 & 15.5 & 12.6 & 15.8 & 14.6 & 16.9 & 15.2 & 0.4 & $* *$ & NS & $* * *$ & $*$ & $\dagger$ & NS & NS \\
\hline Fat, $\%$ & 3.49 & 3.66 & 3.57 & 3.62 & 3.51 & 3.53 & 3.57 & 3.59 & 0.05 & NS & NS & NS & NS & NS & NS & NS \\
\hline Fat, kg/d & 0.60 & 0.51 & 0.59 & 0.48 & 0.59 & 0.55 & 0.64 & 0.58 & 0.02 & * & NS & $* *$ & $\dagger$ & NS & NS & NS \\
\hline Protein, \% & 3.03 & 2.96 & 3.04 & 3.04 & 3.06 & 2.94 & 3.07 & 2.95 & 0.03 & NS & NS & $* *$ & NS & * & NS & NS \\
\hline Protein, kg/d & 0.53 & 0.44 & 0.52 & 0.43 & 0.54 & 0.48 & 0.56 & 0.49 & 0.01 & ** & NS & $* * *$ & $*$ & NS & NS & NS \\
\hline $\mathrm{LSCC}^{3}$ & 13.2 & 13.1 & 13.1 & 13.1 & 13.1 & 13.1 & 13.0 & 13.1 & 0.1 & NS & NS & NS & NS & NS & NS & NS \\
\hline $\mathrm{MUN}^{4}, \mathrm{mg} \%$ & 17.2 & 18.2 & 16.0 & 17.0 & 17.0 & 18.8 & 17.0 & 18.2 & 0.4 & $\dagger$ & * & $* *$ & NS & NS & NS & NS \\
\hline
\end{tabular}

${ }^{1}$ High and low stocking rates for Tifton 85 bermudagrass were 10.0 and 7.5 cows/ha.

${ }^{2}$ High and low stocking rates for Florigraze rhizoma peanut were 7.5 and 5.0 cows/ha.

${ }^{3}$ Natural $\log$ of SCC.

${ }^{4}$ Milk urea nitrogen.

$\dagger P<0.10$.

$* P<0.05$

$* * P<0.01$.

$* * * P<0.001$. 


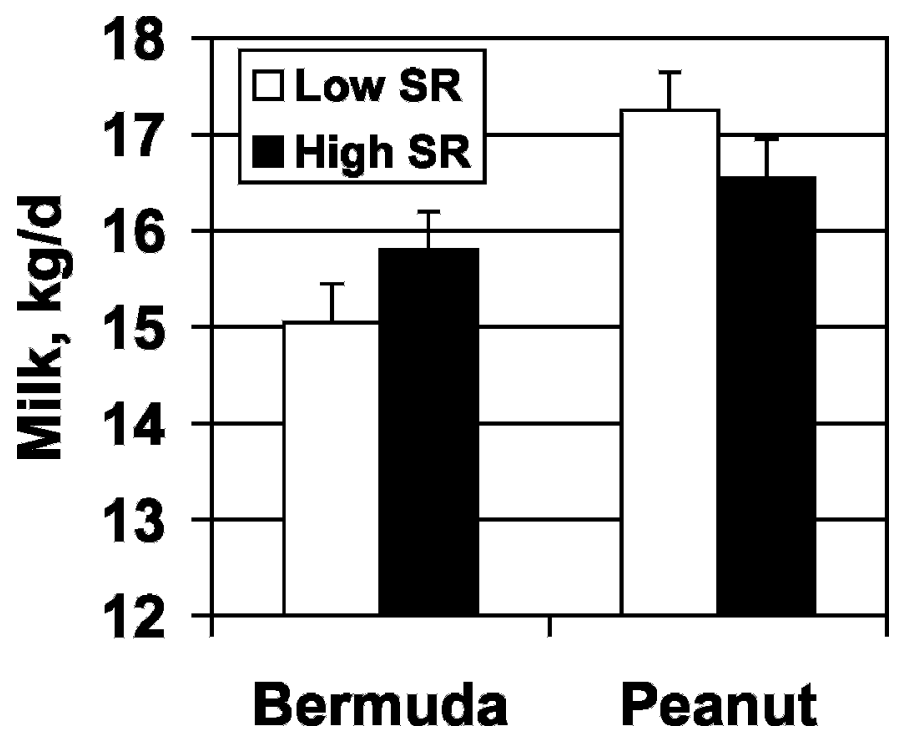

Figure 1. Milk production of Holstein cows grazing bermudagrass at stocking rates (SR) of 7.5 (low) or 10.0 (high) cows per ha and rhizoma peanut at SR of 5 (low) and 7.5 (high) cow per ha. Forage species by $\mathrm{SR}$ interaction was significant $(P<0.05)$.

been more effective to improve milk protein concentration when fed with RP.

The MUN concentrations decreased $(P<0.01) 8 \%$ ( $16.8 \mathrm{vs} .18 .1 \mathrm{mg} / 100 \mathrm{ml}$ of milk) with additional supplement. The milk protein and MUN data together indicate that providing additional supplement resulted in greater ammonia capture by ruminal bacteria. This is

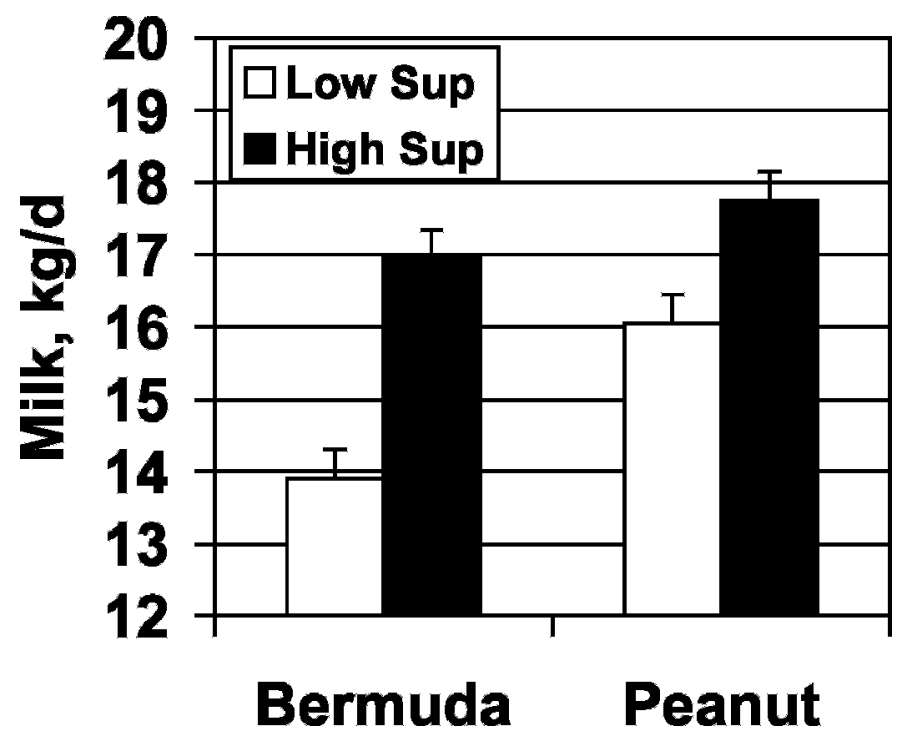

Figure 2. Milk production of Holstein cows grazing bermudagrass or rhizoma peanut pastures and fed concentrate supplement (SUP) at rates of 0.33 (low) or 0.50 (high) $\mathrm{kg} / \mathrm{kg}$ of milk produced. Forage species by SUP rate interaction was significant $(P<0.05)$.

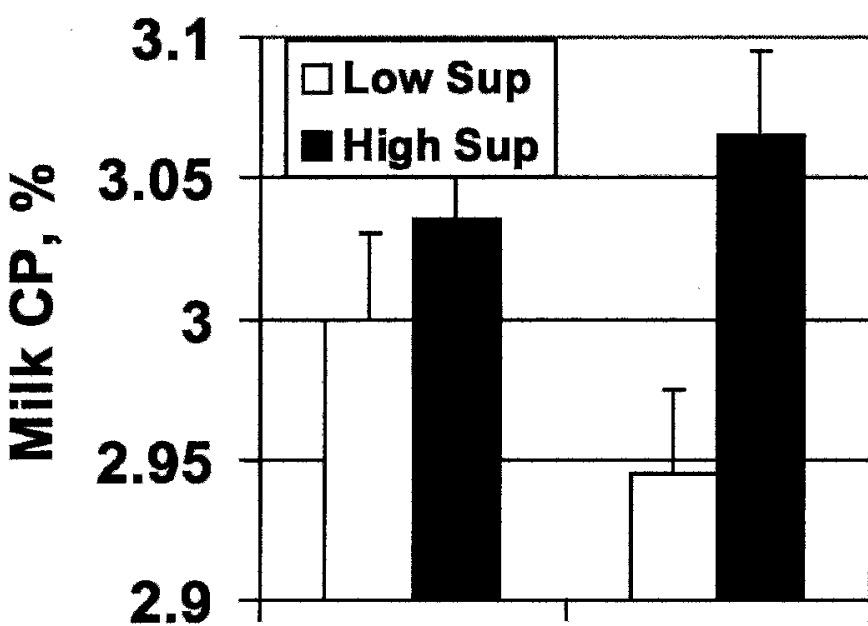

\section{Bermuda Peanut}

Figure 3. Concentration of crude protein of milk from Holstein cows grazing bermudagrass or rhizoma peanut pastures and fed concentrate supplement (SUP) at rates of 0.33 (low) or 0.50 (high) $\mathrm{kg} /$ $\mathrm{kg}$ of milk produced. Forage species by SUP rate interaction was significant $(P<0.05)$.

supported by the work of Reis and Combs (2000) who reported a linear decrease in concentration of ruminal ammonia and milk urea nitrogen as intake of concentrate supplement by grazing dairy cows increased.

\section{Milk Production per Land Area}

Production per land area may be a more appropriate measure of profitability for dairies using grazing systems. Milk production/cow was multiplied by cow/ha (SR), and the resultant milk yields per land area were analyzed without cow effects in the model (Table 4).

Milk produced/ha was greater for BG pastures $(P<$ $0.001)$, high SR $(P<0.001)$, and high SUP $(P<0.01)$ treatments. Stocking rate was the primary determinant of milk produced per land area, with greater SR resulting in about $61 \%$ more milk/ha (119 vs. $80 \mathrm{~kg} / \mathrm{ha}$ per d). Likewise Fales et al. (1995) reported milk production per ha and profits per unit area of land to increase as SR increased from 2.5 to 4.0 cows/ha consisting mainly of orchardgrass, Kentucky bluegrass, and smooth bromegrass. Despite lesser individual animal performance, BG pastures supported an average of $29 \%$ more total milk/ha (112 vs. $87 \mathrm{~kg}$ of milk/ha per d) primarily due to the greater SR used with $\mathrm{BG}$ versus RP pastures. Increasing SUP from 0.33 to $0.50 \mathrm{~kg}$ of supplement per $\mathrm{kg}$ of daily milk increased milk production/ha about $19 \%$ (108 vs. $91 \mathrm{~kg}$ of milk/ha per d). No treatment interactions were detected. 


\section{Body Weight and Condition}

Forage effects. Forage source had no effect on average BW of cows (mean of $509 \mathrm{~kg}$ ) during the experiment (Table 5).

Stocking rate effects. Loss of BW tended to be greater with increased SR of cows on RP (-11.5 vs. -5.5 $\mathrm{kg} / 28 \mathrm{~d}$ ) versus a reduced loss of BW with increased SR of cows on BG pastures ( -1 vs. $-6.5 \mathrm{~kg} / 28 \mathrm{~d}$, forage by SR interaction, $P<0.10$; Figure 4 ). A lower HA for cows stocked at the higher SR on RP pastures (Table 3) may have accounted for the greater loss of BW.

Supplementation rate effects. Supplementation rate had no effect on average BW, however BW changes with SUP tended to be masked by differential responses within each forage. Cows fed more supplement while grazing BG did not lose BW (0 vs. $-7.5 \mathrm{~kg} / 28 \mathrm{~d}$ ), but additional supplement for cows on RP tended to result in greater BW loss ( -11.5 vs. $-5.5 \mathrm{~kg} / 28 \mathrm{~d}$; forage by SUP interaction, $P<0.10$, Figure 5). Increasing the amount of supplement fed may result in greater forage substitution (Davison et al., 1991; Reeves et al., 1996) and may have affected BW changes. The effect of grain feeding on forage intake will be discussed subsequently.

\section{Plasma Urea $\mathbf{N}$ and Glucose}

Forage effects. The PUN averaged $16.4 \mathrm{mg} \%$ and were not different among treatments (Table 5). The PUN response to treatments was not the same as the MUN response (Table 4). Milk urea nitrogen values may be more representative of a cow's urea status since the cow was sampled twice instead of once daily. Plasma glucose concentrations were unaffected by forage species grazed, averaging $58.2 \mathrm{mg} \%$.

Stocking rate effects. Stocking rates did not affect plasma metabolites.

Supplementation rate effects. With greater SUP, cows tended $(P<0.10)$ to have greater plasma glucose concentrations ( $58.8 \mathrm{vs.} 57.5 \mathrm{mg} \%$ ) supporting a greater supply of glucose precursor via supplement.

\section{Respiration Rate and Body Temperatures}

Forage effects. Although RR were not different between cows grazing the two forage species (91 vs. 94 breaths/min), rectal temperatures were greater $(P<$ $0.05)$ for cows on RP vs. BG pastures (39.4 vs. $39.1^{\circ} \mathrm{C}$, Table 5). These greater rectal temperatures coincided with greater milk production by cows on RP (Table 4).

Stocking rate effects. Cows managed at the lower SR experienced greater $(P<0.05)$ RR $(96$ vs. 90 breaths/ $\mathrm{min})$. However this response was forage dependent. Cows that grazed BG at the high SR had much lower $\mathrm{RR}$ than cows grazing $\mathrm{BG}$ at the low SR (86 vs. 96

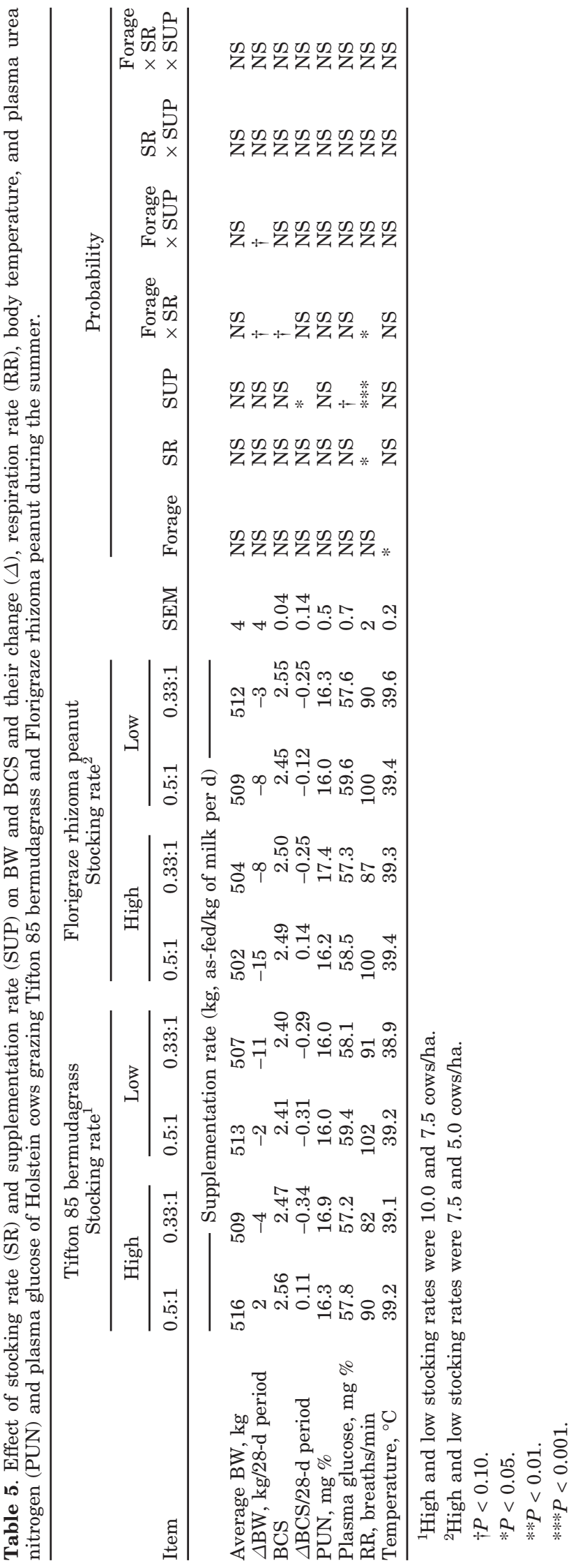




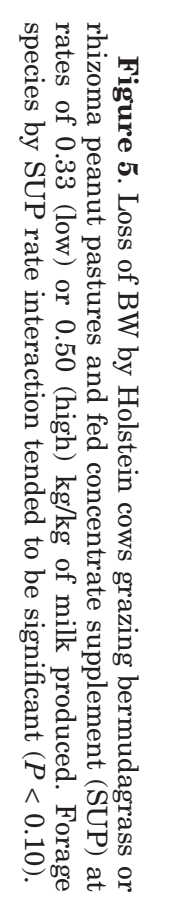

\section{BW loss, $\mathrm{kg} / 28 \mathrm{~d}$}

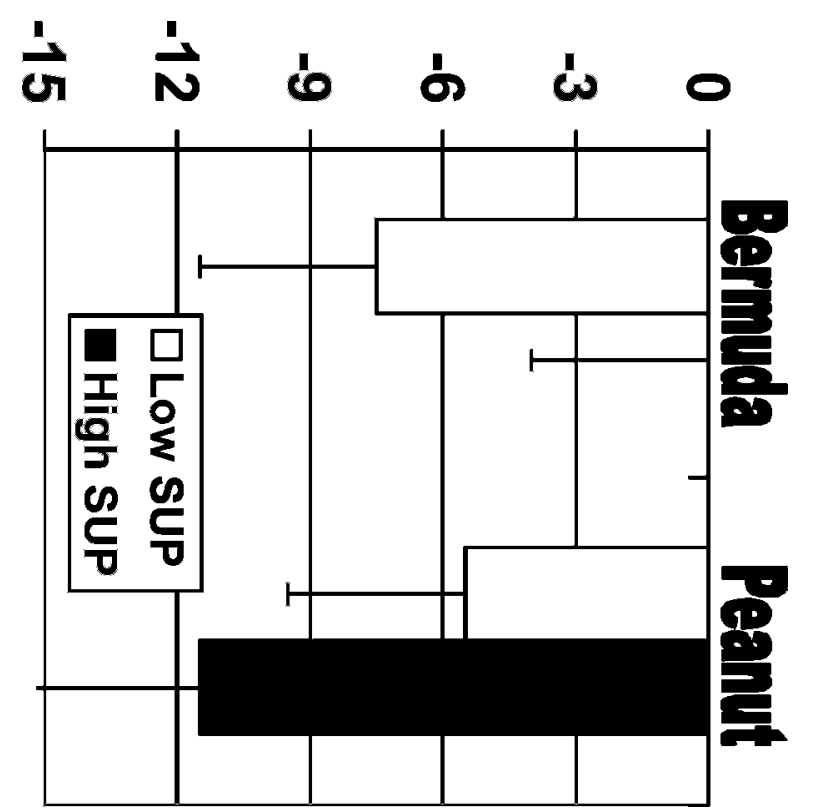

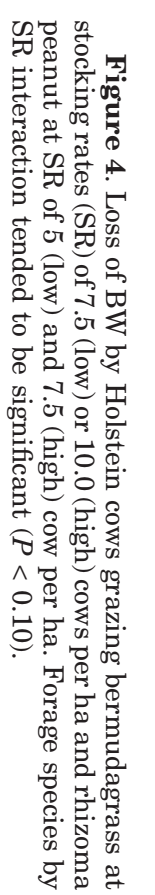

BW loss, $\mathbf{k g} / 28 \mathrm{~d}$

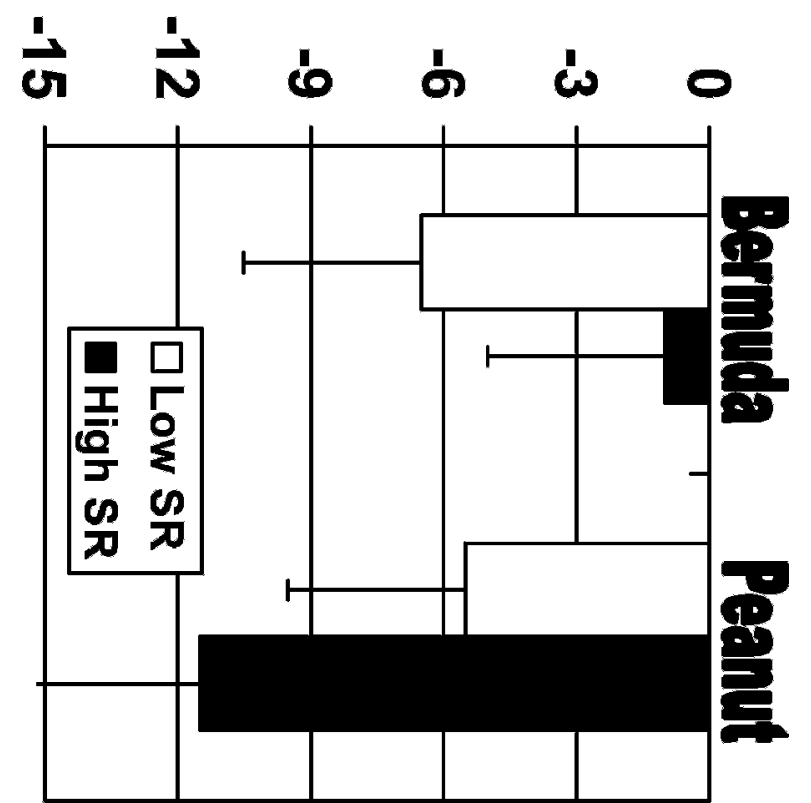

Table 6. Effect of stocking rate (SR) and supplementation rate (SUP) on forage, supplement and total organic matter intake (OMI) of Holstein cows grazing Tifton 85 bermudagrass and Florigraze rhizoma peanut during the summer.

\begin{tabular}{|c|c|c|c|c|c|c|c|c|c|c|c|c|c|c|c|c|}
\hline \multirow[b]{3}{*}{ Item } & \multicolumn{4}{|c|}{$\begin{array}{l}\text { Tifton } 85 \text { bermudagrass } \\
\text { Stocking rate }\end{array}$} & \multicolumn{4}{|c|}{$\begin{array}{c}\text { Florigraze rhizoma peanut } \\
\text { Stocking rate }\end{array}$} & \multirow[b]{3}{*}{ SEM } & \multirow[b]{3}{*}{ Forage } & \multirow[b]{3}{*}{ SR } & \multirow[b]{3}{*}{ SUP } & \multicolumn{3}{|c|}{ Probability } & \multirow{3}{*}{$\begin{array}{l}\text { Forage } \\
\times \text { SR } \\
\times \text { SUP }\end{array}$} \\
\hline & \multicolumn{2}{|c|}{ High } & \multicolumn{2}{|c|}{ Low } & \multicolumn{2}{|c|}{ High } & \multicolumn{2}{|c|}{ Low } & & & & & \multirow{2}{*}{$\begin{array}{l}\text { Forage } \\
\times \text { SR }\end{array}$} & \multirow{2}{*}{$\begin{array}{l}\text { Forage } \\
\times \text { SUP }\end{array}$} & \multirow{2}{*}{$\begin{array}{l}\text { SR } \\
\times \text { SUP }\end{array}$} & \\
\hline & $0.5: 1$ & $0.33: 1$ & $0.5: 1$ & $0.33: 1$ & $0.5: 1$ & $0.33: 1$ & $0.5: 1$ & $0.33: 1$ & & & & & & & & \\
\hline & & Suppl & mentati & rate $(k$ & as-fed/ & g of mil & per d) & 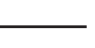 & & & & & & & & \\
\hline Forage OMI, kg/d & 8.5 & 9.6 & 9.7 & 9.1 & 11.5 & 12.5 & 11.9 & 13.9 & 0.9 & $* *$ & NS & NS & NS & NS & $\mathrm{NS}$ & NS \\
\hline SUP OMI, kg/d & 7.1 & 3.8 & 7.1 & 3.8 & 7.7 & 4.5 & 7.6 & 4.6 & 0.1 & $* * *$ & NS & $* * *$ & NS & NS & NS & NS \\
\hline Total OMI, kg/d & 15.6 & 13.4 & 16.7 & 12.9 & 19.2 & 17.0 & 19.5 & 18.5 & 0.8 & $* * *$ & NS & *** & NS & NS & NS & NS \\
\hline Forage OMI, $\%$ of BW & 1.64 & 1.91 & 1.89 & 1.83 & 2.30 & 2.50 & 2.31 & 2.74 & 0.17 & $* * *$ & NS & NS & NS & NS & NS & NS \\
\hline SUP OMI, \% of BW & $\begin{array}{l}1.04 \\
1.42\end{array}$ & 0.74 & 1.39 & 0.77 & 1.55 & 0.90 & 1.49 & 0.92 & 0.03 & $* * *$ & NS & $* * *$ & NS & NS & NS & NS \\
\hline Total OMI, \% of BW & 3.06 & 2.65 & 3.29 & 2.60 & 3.86 & 3.40 & 3.81 & 3.66 & 0.15 & $* * *$ & NS & $* *$ & NS & NS & NS & NS \\
\hline${ }^{1}$ High and low stock & rates & re 10.0 & $\mathrm{~d} 7.5$ & ws/ha. & & & & & & & & & & & & \\
\hline${ }^{2}$ High and low stocki & rates & re 7.5 & $5.0 \mathrm{c}$ & s/ha. & & & & & & & & & & & & \\
\hline$\dagger P<0.10$. & & & & & & & & & & & & & & & & \\
\hline$* P<0.05$ & & & & & & & & & & & & & & & & \\
\hline$* * P<0.01$ & & & & & & & & & & & & & & & & \\
\hline$* * * P<0.001$ & & & & & & & & & & & & & & & & \\
\hline
\end{tabular}


breaths/min) whereas $R R$ of cows on $R P$ were similar regardless of SR (93 vs. 95 breaths/min, forage by SR interaction, $P<0.05$ ). The treatment (BG-high SR) with the lowest $R R(86 / \mathrm{min})$ also lost the least amount of BW $(-1 \mathrm{~kg} / 28 \mathrm{~d})$ suggesting a direct effect of heat load on maintenance costs.

Supplementation rate effects. Supplement rate had no effect on body temperature but feeding the greater SUP caused a $12 \%$ increase $(P<0.001)$ in RR ( 87.5 vs. 98 breaths/min). These measures, indicative of greater energy expenditure, agree with the milk production responses. Greater amount of heat generated during the digestion and lactation processes resulted in a greater heat load on the animals as evidenced by greater RR.

\section{Intake of OM and Nutrients}

Forage effects. Cows grazing RP consumed 35\% more $(P<0.01)$ forage $(12.4 \mathrm{vs} .9 .2 \mathrm{~kg}$ of $\mathrm{OM} / \mathrm{d})$, and supplement $\mathrm{OMI} / \mathrm{d}$ was greater $(P<0.001)$ for those cows due to their greater milk production (Table 6). Total OMI was greater $(P<0.001)$ for cows grazing RP as well (18.5 vs. $14.6 \mathrm{~kg} / \mathrm{d})$. Measures of OMIBW followed the same patterns as OMI. Cows grazing RP pastures had greater $(P<0.001)$ forage $(2.47$ vs. $1.82 \%)$, supplement (1.21 vs. $1.08 \%$ ), and total (3.68 vs. $2.90 \%)$ OMIBW than cows grazing BG pastures. The greater
IVOMD of RP compared to BG (Table 2) and a faster rate of digestion in the rumen (Emanuele and Staples, 1988) probably accounted for the greater DMI. Greater DMI by cows grazing RP only resulted in $1.5 \mathrm{~kg} / \mathrm{d}$ more milk (Table 4). Lack of a greater response may have been due to greater maintenance costs for cooling as cows grazing RP had higher rectal temperatures of $0.3^{\circ} \mathrm{C}$ (Table 5). In addition, the residence time in the rumen of RP as a legume was likely shorter and could have partially compromised it's digestibility advantage over BG.

Stocking rate effects. Stocking rate had no effect on measures of OMI or OMIBW. This was unexpected since HA was lower for cows grazing RP at the high SR (Table 3).

Supplementation rate effects. As expected greater SUP resulted in greater $(P<0.001)$ supplement OMI. The greater supplement OMI with increased SUP led to greater $(P<0.05)$ total OMI despite indications of forage substitution with increased supplement feeding.

The substitution of forage OM by supplement OM $(\mathrm{kg} / \mathrm{kg}$ ) was 0.48 for RP and 0.06 for BG. Though the forage by SUP interaction was not significant for forage OM intake, results showed that feeding additional supplement increased total OM intake by $23 \%$ and $9 \%$ for cows grazing BG and RP pastures, respectively. Substitution rates of supplement for forage were greater for better quality forages (Golding et al., 1976). The forage

Table 7. Calculated daily intake of nutrients by cows grazing Tifton 85 bermudagrass (BG) or Florigraze rhizoma peanut (RP) pastures. Cows received supplement (SUP) at either 0.5 or $0.33 \mathrm{~kg}$ (as-fed) per $\mathrm{kg}$ of daily milk production.

\begin{tabular}{|c|c|c|c|c|c|c|c|c|c|}
\hline \multirow{2}{*}{ Intake } & \multirow{2}{*}{ Requirement $^{3}$} & \multicolumn{4}{|c|}{$\begin{array}{l}\text { Tifton } 85 \text { bermudagrass } \\
\text { Stocking rate }^{1}\end{array}$} & \multicolumn{4}{|c|}{$\begin{array}{l}\text { Florigraze rhizoma peanut } \\
\text { Stocking rate }\end{array}$} \\
\hline & & \multicolumn{2}{|c|}{ High } & \multicolumn{2}{|c|}{ Low } & \multicolumn{2}{|c|}{ High } & \multicolumn{2}{|c|}{ Low } \\
\hline & & & & Suppleme & ion rate & as-fed $/ \mathrm{kg}$ & ailk per $\mathrm{d}$ & & \\
\hline $\mathrm{DM}, \mathrm{kg} / \mathrm{d}$ & 16.0 & 16.6 & 14.2 & 17.9 & 13.7 & 20.9 & 18.5 & 21.2 & 20.1 \\
\hline NEL, Mcal/d & 23.3 & 26.2 & 21.0 & 27.9 & 20.3 & 33.4 & 28.5 & 33.9 & 30.8 \\
\hline $\mathrm{CP}, \mathrm{kg} / \mathrm{d}$ & 2.2 & 2.66 & 2.03 & 2.71 & 2.01 & 3.58 & 3.16 & 3.68 & 3.36 \\
\hline $\mathrm{Ca}, \mathrm{g} / \mathrm{d}$ & 84 & 107 & 80 & 113 & 78 & 289 & 276 & 296 & 303 \\
\hline $\mathrm{P}, \mathrm{g} / \mathrm{d}$ & 54 & 71 & 52 & 74 & 51 & 83 & 65 & 84 & 70 \\
\hline $\mathrm{Mg}, \mathrm{g} / \mathrm{d}$ & 32 & 48 & 39 & 52 & 38 & 85 & 78 & 86 & 85 \\
\hline $\mathrm{K}, \mathrm{g} / \mathrm{d}$ & 144 & 261 & 234 & 283 & 224 & 309 & 280 & 315 & 306 \\
\hline $\mathrm{Na}, \mathrm{g} / \mathrm{d}$ & 29 & 75 & 43 & 76 & 43 & 78 & 46 & 77 & 47 \\
\hline $\mathrm{Zn}, \mathrm{mg} / \mathrm{d}$ & 640 & 1606 & 1088 & 1660 & 1066 & 1788 & 1279 & 1787 & 1353 \\
\hline
\end{tabular}

${ }^{1}$ High and low stocking rates were 10.0 and 7.5 cows/ha on Tifton 85 bermudagrass pastures.

${ }^{2}$ High and low stocking rates were 7.5 and 5.0 cows/ha on Florigraze rhizome peanut pastures.

${ }^{3}$ Calculations based on NRC (1989) requirements for a $500 \mathrm{~kg}$ cow producing $20 \mathrm{~kg}$ of $4.0 \% \mathrm{FCM}$ and gaining $0.275 \mathrm{~kg} / \mathrm{d}$. Intake was assumed to be $3.2 \%$ of BW. 
Table 8. Effect of stocking rate (SR) and supplementation rate (SUP) on BW change, 4\% FCM production, and measures of energy (E) status of Holstein cows grazing Tifton 85 bermudagrass and Florigraze rhizoma peanut.

\begin{tabular}{|c|c|c|c|c|c|c|c|c|c|c|c|c|c|c|c|c|}
\hline \multirow[b]{3}{*}{ Item } & \multicolumn{4}{|c|}{$\begin{array}{l}\text { Tifton } 85 \text { bermudagrass } \\
\text { Stocking rate }\end{array}$} & \multicolumn{4}{|c|}{$\begin{array}{l}\text { Florigraze rhizoma peanut } \\
\text { Stocking rate }\end{array}$} & \multirow[b]{3}{*}{ SEM } & \multirow[b]{3}{*}{ Forage } & \multirow[b]{3}{*}{ SR } & \multirow[b]{3}{*}{ SUP } & \multicolumn{3}{|c|}{ Probability } & \multirow{3}{*}{$\begin{array}{l}\text { Forage } \\
\times \text { SR } \\
\times \text { SUP }\end{array}$} \\
\hline & \multicolumn{2}{|c|}{ High } & \multicolumn{2}{|c|}{ Low } & \multicolumn{2}{|c|}{ High } & \multicolumn{2}{|c|}{ Low } & & & & & & & & \\
\hline & $0.5: 1$ & $0.33: 1$ & $0.5: 1$ & $0.33: 1$ & $0.5: 1$ & $0.33: 1$ & $0.5: 1$ & $0.33: 1$ & & & & & $\times \mathrm{SR}$ & $\times$ SUP & $\times$ SUP & \\
\hline & & - Supple & nentati & rate $(\mathrm{k}$ & as-fed & $\mathrm{g}$ of $\mathrm{mil}$ & per d) & 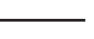 & & & & & & & & \\
\hline Average BW, kg & 509 & 503 & 508 & 509 & 499 & 500 & 504 & 513 & 3 & NS & $*$ & NS & NS & NS & NS & NS \\
\hline $\mathrm{FCM}, \mathrm{kg} / \mathrm{d}$ & 16.6 & 14.3 & 16.7 & 14.2 & 16.1 & 15.6 & 16.8 & 15.4 & 0.4 & $\dagger$ & NS & $* * *$ & NS & $*$ & NS & NS \\
\hline Maintenance E, Mcal/d ${ }^{3}$ & 10.1 & 10.1 & 10.1 & 10.1 & 10.0 & 10.0 & 10.1 & 10.2 & 0.1 & NS & $*$ & NS & NS & NS & NS & NS \\
\hline FCM E, Mcal/ $/ \mathrm{d}^{4}$ & 12.3 & 10.7 & 12.4 & 10.5 & 11.9 & 11.6 & 12.4 & 11.4 & 0.3 & $\dagger$ & NS & $* * *$ & NS & * & NS & NS \\
\hline Total E output, Mcal// $\mathrm{d}^{5}$ & 22.4 & 20.7 & 22.5 & 20.3 & 21.9 & 21.6 & 22.5 & 21.6 & 0.3 & NS & NS & $* *$ & NS & * & NS & NS \\
\hline BW change, kg/d & -0.2 & -0.3 & -0.1 & 0.0 & -0.5 & -0.4 & -0.2 & -0.1 & 0.1 & NS & * & NS & NS & NS & NS & NS \\
\hline Tissue E, Mcal $/ \mathrm{d}^{6}$ & 1.0 & 1.4 & 0.5 & 0.1 & 2.6 & 1.7 & 0.9 & 0.5 & 0.6 & NS & * & NS & NS & NS & NS & NS \\
\hline Forage $\mathrm{E}$ intake, Mcal/d & 5.9 & 9.6 & 7.5 & 7.9 & 8.8 & 14.3 & 11.2 & 15.5 & 0.8 & $* * *$ & NS & $* * *$ & NS & * & NS & NS \\
\hline Suppl. E intake, Mcal// $\mathrm{d}^{8}$ & 14.8 & 8.0 & 14.2 & 8.2 & 16.0 & 9.1 & 15.1 & 8.8 & 0.3 & $* *$ & NS & $* * *$ & NS & NS & NS & NS \\
\hline Dietary intake E, Mcal/d & 20.7 & 17.6 & 21.7 & 16.2 & 24.8 & 23.5 & 26.3 & 24.4 & 0.7 & $* * *$ & NS & $* * *$ & NS & * & NS & NS \\
\hline Total E input, Mcal/d & 21.6 & 19.0 & 22.3 & 16.4 & 27.4 & 25.2 & 27.2 & 28.4 & 0.9 & $* * *$ & NS & $* * *$ & NS & NS & NS & NS \\
\hline E status, Mcal $/ \mathrm{d}^{9}$ & -0.8 & -1.7 & -0.2 & -4.3 & 5.5 & 3.6 & 4.7 & 3.2 & 1.0 & $* * *$ & NS & $*$ & NS & NS & NS & NS \\
\hline
\end{tabular}

${ }^{1}$ High and low stocking rates for Tifton 85 bermudagrass were 10.0 and 7.5 cows/ha

${ }^{2}$ High and low stocking rates for Florigraze rhizoma peanut were 7.5 and 5.0 cows/ha.

${ }^{3}$ Calculated using NRC equations for maintenance and activity, maintenance $\mathrm{E}=0.073 \times \mathrm{BW}^{0.75}$. Requirement was also increased $25 \%$ for energy of activity and increased an additional $10 \%$ above maintenance for primiparous cows.

${ }^{4}$ Calculated using NRC equations, milk energy $=0.74 \mathrm{Mcal} / \mathrm{kg} \times \mathrm{FCM}, \mathrm{kg} / \mathrm{d}$.

${ }^{5}$ Total E output = Maintenance E + FCM E, Mcal/d.

${ }^{6}$ Calculated using NRC (1989) equations. Tissue $\mathrm{E}=+4.92 \mathrm{Mcal} / \mathrm{kg}$ BW loss and $-5.12 \mathrm{Mcal} / \mathrm{kg} \mathrm{BW}$ gain.

${ }^{7}$ Calculated using the NRC (1989) conversion of TDN to NEL, where NEL $=[0.0245 \times$ TDN (\% of DM) -0.12$]$. Calculation of TDN was based on the equation for estimation of TDN in warm-season grasses used by the University of Florida Forage Evaluation Support Laboratory (J. E. Moore, personal communication), where \% TDN = [(IVOMD, $\% \times 0.49)+32.2] \times$ OM concentration.

${ }^{8}$ Calculated using estimated supplement digestibility of 86\%. TDN was calculated using tabular values, and NEL was calculated from estimated TDN using NRC (1989) equations.

${ }^{9}$ Energy status = Energy input - energy output.

$\dagger P<0.10$.

$* P<0.05$.

** $P<0.01$.

$* * * P<0.001$. 
by supplement interaction observed for milk production (Table 4) further supports the evidence of greater substitution rates of grain for forage for cows grazing $R P$ in that milk response was superior for cows grazing BG compared to those grazing $\mathrm{RP}$ when additional supplement was fed. One application of this response is that the SR could be increased in proportion to the decrease in forage consumption when feeding the greater amount of supplement.

Intakes of selected nutrients were calculated based upon chemical analysis and calculated intake of forages and supplement. When compared to the nutrient requirements of a $500 \mathrm{~kg}$ cow producing $20 \mathrm{~kg}$ of milk and gaining $0.275 \mathrm{~kg} / \mathrm{d}(\mathrm{NRC}, 1989)$, intake of all nutrients by cows grazing RP pastures were in excess of requirements (Table 7). A supplement containing less soybean meal and no Ca carbonate would be satisfactory for cows grazing RP under the conditions of the current experiment. Such a supplement however may reduce milk protein concentration as the protein in $\mathrm{RP}$ appears to be less digestible than that found in typical legumes. Cows grazing BG and fed at the lower supplementation rate were consuming a diet deficient in crude protein $(\sim 200 \mathrm{~g} / \mathrm{d})$ and just slightly deficient in $\mathrm{Ca}(4$ to $6 \mathrm{~g} / \mathrm{d})$ and $\mathrm{P}(2$ to $3 \mathrm{~g} / \mathrm{d}$ ) (Table 8). Therefore the response in milk production to the higher supplementation rate $(0.8 \mathrm{~kg} / \mathrm{kg}$ of supplement) may have been due partially to the alleviation of a CP deficiency.

Intake, production, and BW data were used to calculate the effect of treatments on energy status of cows (Table 8). Naturally, only those cows from which intake estimates were calculated were used $(n=32)$. Calculated total energy inputs were greater than total outputs for cows grazing RP compared to those on BG; that is, cows on RP were in positive energy status (4.2 vs. $-1.75 \mathrm{Mcal} / \mathrm{d}$ ). However, mean BW change was neutral $(\mathrm{n}=1)$ or negative $(\mathrm{n}=7)$ for all treatment groups (Table 5 ), suggesting that cows were in negative or, at best, neutral energy status. If cows grazing $\mathrm{RP}$ were in less positive energy status than calculations indicate, were calculations of energy inputs or outputs the more likely source of error. The measures of FCM production and BW were considered sound and equations for calculating energy content of each variable have been well verified (NRC, 1989). The error could have been in the maintenance energy requirement value but the value used was increased from 10 to $25 \%$ because cows were exposed to a great deal of heat stress and had to walk extensively. Energy input may have been overestimated due to an overestimation of intake of forage, of digestibility of forage, of digestibility of supplement, or a combination thereof. The digestibility of concentrates is fairly rapid and consistent. However the digestibility of the forage fraction of the diet is likely to vary from
IVOMD values due to associative effects. If the pulsedose technique involving $\mathrm{Cr}$-mordanted forage overestimates fecal output, the estimate of intake would, in turn, be inflated as well. Using the same techniques as employed in the current study, Galyean (1993) estimated fecal output to be no different from that measured using the total collection method involving $46-\mathrm{kg}$ lambs consuming alfalfa hay or prairie hay with or without sorghum grain. However the mean fecal output calculated using the marker methods was 22 to $27 \%$ greater than the mean for the total collection method when prairie hay was fed. If fecal output was overestimated in the current study, then DMI, energy intake, and energy balance all would be overestimated as well.

\section{CONCLUSIONS}

For dairy farm managers practicing grazing management, RP is likely to be of limited use in southeastern U.S. dairy grazing systems until $\mathrm{N}$ fertilizers become prohibitively expensive. The greater milk production per cow associated with RP cannot compensate for the forage's limited ability to support large numbers of lactating cows per ha. An appropriate SR for RP pastures appears to be approximately 5 cows per ha when supplement is offered. Tifton 85 bermudagrass, however, appears to be an excellent forage for dairy cow grazing in the southeastern U.S. given its nutritive value characteristics and high yields. An optimum stocking rate can be as high as 10 cows/ha during times of peak growth of forage for moderately producing dairy cows fed supplement.

The positive milk production response to additional supplement $(0.8 \mathrm{~kg} / \mathrm{kg}$ of supplement $)$ when cows grazed BG pastures indicate the value of providing substantial amounts of supplement to cows grazing this moderate quality forage and stand in contrast to the limited production response to supplement when cows grazed RP. Feeding supplement at a rate of $0.5 \mathrm{~kg} / \mathrm{kg}$ of milk produced resulted in a BG forage to concentrate ratio of 56:44 (DM basis), one that should not be conducive to ruminal acidosis or depressed milk fat percentage.

\section{ACKNOWLEDGMENTS}

The authors thank Dale Hissem, James Lindsey, and Mary Russell at the research farm for their assistance during the conduction of the experiments. Appreciation also is expressed to Estelle Hirchert, Jocelyn Jennings, Joyce Hayen, and Osmar Carrijo for their help at the farm and in the lab. Generous financial support from the Florida Milk Cooperatives and American Farm Bureau is acknowledged. 


\section{REFERENCES}

AOAC. 1990. Official Methods of Analysis. Vol. I. 15th Ed. AOAC. Arlington, VA. Arriaga-Jordan, C. M., and W. Holmes. 1986. The effect of cereal concentrate supplementation on the digestibility of herbage-based diets for lactating dairy cows. J. Agric. Sci. (Camb.) 106:581-592.

Berzaghi, P., J. H. Herbein, and C. E. Polan. 1996. Intake, site, and extent of nutrient digestion of lactating cows grazing pasture. J. Dairy Sci. 79:1580-1589.

Blaxter, K. L., and R. S. Wilson. 1963. The assessment of a crop husbandry technique in terms of animal production. Anim. Prod. 5:27-42.

Cowan, R. T., and P. O. O'Grady. 1976. Effect of presentation yield of a tropical grass-legume pasture on grazing time and milk yield of Friesian cows. Trop. Grasssl. 10:213-218.

Dartt, B. A., J. W. Lloyd, B. R. Radke, J. R. Black, and J. B. Kaneene. 1999. A comparison of profitability and economic efficiencies between management-intensive grazing and conventionally managed dairies in Michigan. J. Dairy Sci. 82:2412-2420.

Davison, T. M., D. Williams, W. N. Orr, and A. T. Lisle. 1991. Responses in milk yield from feeding grain and meat-and-bone meal to cows grazing tropical pastures. Aust. J. Exp. Agric. 31:159-163.

Emanuele, S. M., and C. R. Staples. 1988. Effect of forage particle size on in situ digestion kinetics. J. Dairy Sci. 71:1947-1954.

Fales, S. L., L. D. Muller, S. A. Ford, M. O'Sullivan, R. J. Hoover, L. A. Holden, L. E. Lanyon, and D. R. Buckmaster. 1995. Stocking rate affects production and profitability in a rotationally grazed pasture system. J. Prod. Agr. 8:88-96.

Gallaher, M. L., C. L. Weldon, and J. G. Futral. 1975. An aluminum block digestor for plant and soil analysis. Soil Sci. Amer. Proc. 39:803-806.

Galyean, M. L. 1993. Technical note: An algebraic method for calculating fecal output from a pulse dose of an external marker. J. Anim. Sci. 71:3466-3468.

Gelaye, S., E. A. Amoah, and P. Guthrie. 1990. Performance of yearling goats fed alfalfa and florigraze rhizoma peanut hay. Small Rum. Res. 3:353-361.

Goering, H. K., and P. J. Van Soest. 1970. Forage Fiber Analyses. Agric. Handbook No. 379 ARS-USDA, Washington, DC.

Golding, E. J., J. E. Moore, D. E. Franke, and O. C. Ruelke. 1976 Formulation of hay-grain diets for ruminants. II. Depression in voluntary intake of different quality forages by limited grain in sheep. J. Anim. Sci. 42:717-723.

Hambleton, L. G. 1977. Semiautomated method of simultaneous determination of phosphorus, calcium, and crude protein in animal feeds. J. Am. Org. Anal. Chem. 60:845-852.

Hongerholt, D. D., and L. D. Muller. 1998. Supplementation of rumenundegradable protein to the diets of early lactation Holstein cows on grass pastures. J. Dairy Sci. 81:2204-2214.

Jones-Endsley, J. M., M. J. Cecava, and T. R. Johnson. 1997. Effects of dietary supplementation on nutrient digestion and the milk yield of intensively grazed lactating dairy cows. J. Dairy Sci. 80:3283-3292

King, K. R., and C. R. Stockdale. 1980. The effects of stocking rate and nitrogen fertilizer on the productivity of irrigated perennial pasture grazed by dairy cows. 2. Animal production. Aust. J. Exp. Agric. Husb. 20:537-542.

Mandevbu, P., J. W. West, R. N. Gates, and G. M. Hill. 1998. In vitro digestion kinetics of neutral detergent fiber extracted from Tifton 85 and Coastal bermudagrasses. Anim. Feed Sci. Tech. 73:263269

Meijs, J. A. C., R. J. K. Walters, and A. Keen. 1982. Sward methods. Pages 11-36 in Herbage Intake Handbook. J. D. Leaver ed. Brit. Grassl. Soc. Hurley, U.K.

Moore, J. E., W. E. Kunkle, M. H. Brant, and D. I. Hopkins. 1999 Effects of supplementation on voluntary forage intake, diet digestibility, and animal performance. J. Anim. Sci. 77(Suppl. 2):122-135.

Moore, J. E., and G. O. Mott. 1974. Recovery of residual organic matter from in vitro digestion of forages. J. Dairy Sci. 57:1258 1259. Forage Sci. 43:215-230.

National Research Council. 1989. Nutrient Requirements of Dairy Cattle. 6th rev. ed. Natl. Acad. Sci., Washington, DC.

Parker, W. J., L. D. Muller, and D. R. Buckmaster. 1992. Management and economic implications of intensive grazing on dairy farms in the northeastern states. J. Dairy Sci. 75:2587.

Pond, K. R., J. C. Burns, and D. S. Fisher. 1987. External markersUse and methodology in grazing studies. Pages 49-53 in Proc. Grazing Livestock Nutrition Conf. Jackson, Wyoming.

Reeves, M., W. J. Fulkerson, and R. C. Kellaway. 1996. Production responses of dairy cows grazing well-managed kikuyu (Pennisetum clandestinum) pastures to energy and protein supplementation. Aust. J. Exp. Agric. 36:763-770.

Reis, R. B., and D. K. Combs. 2000. Effects of increasing levels of grain supplementation on rumen environment and lactation performance of dairy cows grazing grass-legume pastures. J. Dairy Sci. 83:2888-2898.

Roseler, D. K., J. D. Ferguson, C. J. Sniffen, and J. Herrema. 1993. Dietary protein degradability effects on plasma and milk urea nitrogen and milk nonprotein nitrogen in Holstein cows. J. Dairy Sci. 76:525-534.

SAS Institute Inc. 1991. SAS System for Linear Models. 3rd ed. Cary, NC.

Sollenberger, L. E., and J. E. Moore. 1997. Assessing forage allowance-animal performance relationships on grazed pasture. Agron. Abst. 140-141.

Staples, C. R., S. M. Emanuele, and G. M. Prine. 1997. Intake and nutritive value of Florigraze rhizoma peanut silage for lactating dairy cows. J. Dairy Sci. 80:541-549.

Udén, P., P. E. Colucci, and P. J. Van Soest. 1980. Investigation of chromium, cerium and cobalt as markers in digesta. Rate of passage studies. J. Sci. Food Agric. 31:625-632.

Williams, C. H., D. J. David, and O. Hsmaa. 1962. The determination of chromic oxide in faeces samples by atomic absorption spectrophotometry. J. Agric. Sci. (Camb.) 59:381-385. 